\title{
History of Medical Treatment Present
}

National Cancer Institute

\section{Source}

National Cancer Institute. History of Medical Treatment Present. NCI Thesaurus. Code C160179.

An indication that a history of medical treatment is present. 